\title{
Students Perception to Case Based Learning and Problem Based Learning in a Nursery College
}

Azra Shaheen, Lahore School of Nursing, The University of Lahore, Lahore, Pakistan

Email: Neelu7219@gmail.com; Mobile: 03024094546

ORCID: http://orcid.org/0000-0001-5130-335X

Muhammad Afzal, Lahore School of Nursing, the University of Lahore, PO box 54000, Lahore, Pakistan Email:Muhammad.Afzal@Isn.uol.edu.pk

Mobile:0333-2186533

Muhammad Hussain, Lahore School of Nursing, the University of Lahore, PO box 54000, Lahore, Pakistan

E-mail:Muhammad.Hussain@Isn.uol.edu.pk

Mobile:0300-2105089

Syed Amir Gilani, FAHS the University of Lahore, PO box 54000, Lahore, Pakistan. Email: profgilani@gamil.com

Mobile:+92 (0)42 35321761, (+92) 42 111-865-865

Correspondence author: Azra Shaheen, Lahore School of Nursing, The University of Lahore, Lahore, Pakistan; Email: Neelu7219@gmail.com; Mobile: 03024094546 ORCID: http://orcid.org/0000-0001-5130-335X Received:16/2/2020 Accepted: 21/3/2020 Published: $1^{\text {st }}$ May, 2020

\begin{abstract}
Background: $\mathrm{PBL}$ and $\mathrm{CBL}$ are described as favorable tools for medical profession. Therefore, it is necessary to know the feedback from those students who had CBL for two years undergraduate medical curriculum and were successively exposed to PBL. This study aimed at comparing CBL with PBL based on the perception of the students who observed this transition of learning methodologies in the medical curriculum.
\end{abstract}

Objective:Objective of the study was to explore the perceptions of the students 'about Case base learning and problem base learning.

Study design: Cross sectional study. 
Setting:The study is carried out at the University of Lahore Pakistan which is organized by the Commission for Higher Education.

Duration: 4 months from September 2019 to December 2019.

Methodology:Students of MBBS department in The University of Lahore Pakistan was target population of this research study.

Results:The full response from 133 students was received. PBL was favored by eighty four percent of students over CBL $(p<0.01)$. PBL enabled students dramatically to recognize knowledge gaps, develop their areas of weakness, manage time, make decisions, solve problems, use critical reasoning skills and interact with each other $(p<0.01)$ relative to CBL It improved the ability to find online and library content. Students suggested that PBLs be time-consuming and that adequate facilitator training be provided in comparison with CBL. Both were convinced by the CBL education system led by PBL

Conclusion:The PBL was effective in terms of idea retention, critical reasoning and problem-solving strategies, but satisfied with the current educational system elucidated CBL's role in the first two years of undergraduate medical training in preparing students through controlled investigation and clinical scenarios presentation. Proper facilitator preparation will be a key point to enhance student learning by PBLs.

Keywords: case based learning, medical students, Problem based learning

\section{Introduction}

Problem-based learning (PBL) is an educational approach that reflects a resourceful way of thinking about teaching and learning. PBL is a student group-focused education that uses an inquiry-based tutorial approach to learning [1]. PBL is considered by small group that uses tutorials rather than lectures as opposed to informative learning, lecture based curriculum and it is commonly used in medicine and the health sciences in combination with traditional learning methodologies, as it helps students to develop the higher order thinking skills required to be successful in the medical profession [2]. CBL is an approach to medical education, which aims to prepare students for clinical practice, using real medical issues. These issues are linked to the theory in their affairs through the application of theoretical knowledge and encourage the use of inquirybased teaching methods learning [3]. A common learning class is 
considered case-based learning. It usually involves shared scenarios aligned with defined learning outcomes with educational value that fosters interest, empathizes with characters, and generally applies [4].

Under the current complicated medical environment, the aim of medical colleges and universities is to cultivate medical talents with a sense of innovation, high comprehensive ability and high quality [5]. CBL (case-based learning) is an effective teaching method with which the teacher analyzes and discusses the relevant theoretical knowledge based on a typical clinical case in the teaching of students. The teaching model can improve the students' ability of analyzing and solving problems, and realize the purpose of combining theory with practice [6]. Therefore, allowing students to master a wide range of knowledge and practical skills in a short time is a very difficult task. For medical education, problem-based learning (PBL) and case-based learning (CBL) have become perfect teaching methodologies by means of which students clear the majority of their confusions and misunderstandings as a result of general discovery learning strategies [7]. It usually involves common scenarios associated with defined learning outcomes that have educational value which stimulate interest, create empathy with the characters and usually have general applicability [8]. The students in CBL are usually provided with articles and learning resources about the topic and the group is then assigned the role to present the material. In contrast, in PBL the students are required to use additional resources either during or after the PBL sessions [9].

Many medical institutes in Pakistan have introduced PBL in their curriculum but very few of them have included both CBL and PBL as instructional strategies in their medical curriculum. It is responsibility of every institute to introduce in the sense that in the first two years of medical education, CBL remains an integral part of the curriculum while PBL is introduced from third year till the final (fifth year) [10].

The medical educationists are aware of the fact that PBL and CBL are described as auspicious tools for medical and dental educators [11]. Therefore, this research purpose is wanted to know the feedback of those students who experienced CBL for two years of undergraduate medical curriculum and were then exposed to PBL. The objective of our study was to compare CBL with PBL on the basis of perception of the students who have observed this transition of 
learning methodologies in the undergraduate medical curriculum related learning [12]. Problem-based learning (PBL) is now used at many medical schools to promote lifelong learning, open inquiry, teamwork, and critical thinking. PBL has not been compared with other forms of discussion-based small-group learning. Case-based learning $(\mathrm{CBL})$ uses a guided inquiry method and provides more structure during small-group sessions [13].

\section{Aim of the study}

The purpose of the study was to explore the perceptions of the students 'about Case base learning and problem base learning among undergraduates.

\section{Significance of the study}

Students who have significant deficiencies in expressing ideas or communication skills are likely to be unsuccessful in a PBL program. PBL requires the ability to process and discuss ideas which learn independently. It thus seems likely that with a guided inquiry approach as in CBL. The students might find the problem solving exercises interesting and this might as well improve their academic performance. This study will increase confidence of student. After this research student will be able to use this study for further more researches with their abilities in institution. To increase student selfabilities and confident institution will hire more facilities for students. This study is conducted on medical students by nursing student. This study will show the abilities of nursing student in other department, which will increase the good image and perception of nursing department.

\section{Literature review}

In two major academic medical centers, students and teachers preferred CBL (Guided Inquiry) to PBL (Open Inquiry). Given the dense medical curriculum and the need for student and faculty time to be used effectively, CBL offers an alternative model for traditional PBL small group education. This study was unable to determine which method produces better therapists. Lifelong education, open discussion, collaboration and critical thinking are now being used in many medical schools. PBL was not associated with other small group training. Case-based learning (CBL) uses guided inquiry and in small group sessions provides more structure. In this study, compare the views of students on traditional PBL with $\mathrm{CBL}$ in two institutions after curriculum changes [14]. Innovative teaching methods focus on 
developing critical knowledge, problem solving behavior, selfdirected learning strategies and team participation skills in medical undergraduates [15]. The notes of point of view is a well-rounded medical expert who acts as a medium for passing interest [16]. Some studies have emphasized that there is no need to evaluate that this approach will always help to arrive at definitive answers, but the focus should be on defending its proposed solution and reasoning [17].

We feel a teaching method can be successful and will be able to draw students' attention when it is not only interesting, informative and clinical oriented but is also able to fetch better marks for the students in the examinations and assessment tests [18]. The newer innovative small group interactive teaching is a better process to learn the medical subject than traditional teaching. Some academicians are of the opinion that the most important purpose of such small group interactive teaching methods is to provide a clinical context for the acquisition of knowledge, rather than to solve the problem [19]. This study indicates that the use of CBL and PBL is well documented in Medical Education. The subjects in basic sciences can be associated with these approaches. This result may be explained by the large amount of literature being published, and because other medical areas like Allied Health and Pharmacy, represent a younger existence when compared with traditional Medical education [20]. While addressing the effectiveness of CBL and PBL as learning vehicles in comparison to traditional didactic lectures, the study also compares CBL and PBL as an effective learning method by focusing on the academic outcomes of students [21]. From the present study it can be concluded that CBL can be used as an innovative teaching method for better retention of knowledge, clarity of subject and application of biochemistry in medicine. This innovative teaching-learning methodology is student centered and achieves greater learner satisfaction [22]. From the present study it can be concluded that $\mathrm{CBL}$ can be used as an innovative teaching method for better retention of knowledge, clarity of subject and application of biochemistry in medicine. This innovative teaching-learning methodology is student centered and achieves greater learner satisfaction [22].

Problem-based learning (PBL) and case-based learning (CBL) are teaching methodologies, which regulate self-directed learning skills. In medical schools of Pakistan either or both are being consistently used in the undergraduate and postgraduate curriculum. 
The objective of our study was to compare CBL with PBL on the basis of perception of those students who have observed this transition of learning methodologies in the undergraduate medical curriculum of students [23].

\section{Theoretical framework}

PBL
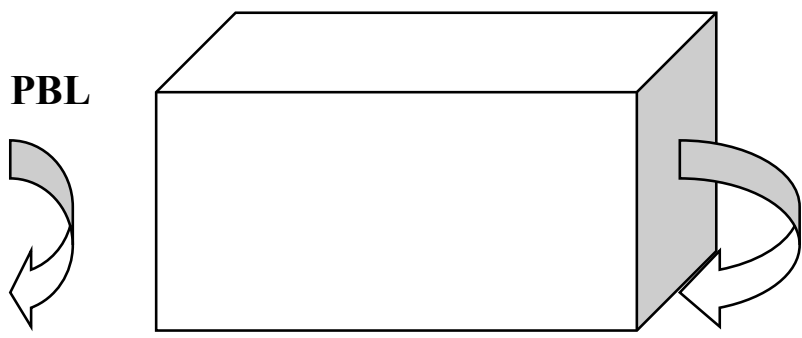

Active learning

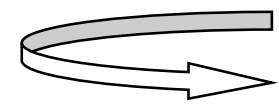

CBL

The relationship between Problem base learning with case base learning is less clear .Case base learning is approaches that fall under the term of PBL. PBL (minutes to hours) typically much better with CBL (hours to weak).Both PBL and CBL are affected for active and skill base learning. Often start with general them or issue from which student develop a particular question to be addressed. Research team decided that PBLis more perspective and focused than CBL [24].

\section{Methodology}

\section{Study design}

For this study, a quantitative cross-sectional descriptive study design will be used to assess case-based knowledge and problembased learning.

\section{Study site}

The study will be carried out at the University of Lahore

Pakistan which is organized by the Commission for Higher Education.

\section{Duration}

The study was conducted from September 2019 to December 2019 over a period of four month.

\section{Population}

The targeted population of this Study was MBBS student's population of this research study. 


\section{Sampling}

A convenient sampling method was used for this study. It is the easiest and the most convenient method of engaging the sources of the primary data for research.

\section{Research instrument}

PBL over case based learning (CBL) adopted from (23). The questionnaire will distribute among MBBS Students University of Lahore. An adopted 31-item questionnaire was used in this study which is developed at the Agha Khan University of Karachi. Pilot study was done to check filling the questionnaire from ten respondents. Reliability was 0.96 and validity was 0.65 which shows that the questionnaire used for collecting the participant's responses is reliable and valid.

\section{Data gathering procedure}

Data collected from students of MBBS department of the University of Lahore,

\section{Methods used for data analyses}

Data analysis will be done by SPSS version 21.Statistical computer software for data analysis. The study will be descriptive study and all the descriptive statistics will be obtained through the SPSS software.

\section{Ethical consideration}

Offer the participant full research-related information.This means that the individual was not hurt. The analysis was successful. Both patients had an open forum for research participation. No one was forced to take part in testing. The individual signed the informed consent document in both the Urdu and English languages. The information or data was being remained to the first researcher.

\section{Results and discussion}

The distribution of participant by demographic characteristics are shown in Table 1. The complete response was obtained from 133 students, out of which $83(60.1 \%$ were males and $48(36.1 \%)$ females. Table 2 elaborate 133 students received the complete response, 83 of whom were male and 48 were female. Students in the third year of their undergraduate medical program found that PBL strategy was more important than CBL in the first two years of medical education. In addition, PBL problems have given rise to contextual awareness, which has raised interest in learning and is comparable to other studies [25]. Research has shown that students in the second year reacted 
more successfully to PBL than in the first year. Students in this study have learned about real medical conditions and handled the patients with the help of PBLs a step forward.PBLs encourage students to use databases and reference books as the pre-reading material is not given in advance [26]. Response from online PBL sessions was given in a research and students said with this learning technique they gained a lot of information. An analysis revealed participation of librarians in the development and implementation of PBL curricula and directed policy makers and PBL practitioners in the development of curricula [27]. It is the duty of facilitators to create an environment for learners to develop their own knowledge, skills and values through interaction [28]. Although the PBL proposed that researchers be an "open investigation," our students stressed the role of the facilitator in developing theoretical knowledge of clinical cases, the diagnostic characteristics and their management. The literature has reported the need for facilitator learning to make such rules for them in order to become effective facilitators [29]. On the contrary, the students did not recommend CBL facilitator practice. The ability to think logically and rationally about what to do or believe is critical thinking. PBL is an effective strategy that enhances critical thinking, scientific reasoning and the capacity of medical students to solve problems [30]. The findings (Table-1) indicate that students found PBL to be interesting compared to CBL $(\mathrm{p}<0.01)$, but it took more time. PBL significantly helped students identify knowledge gaps and more than CBL $(p<0.01)$ improved their areas of weakness. They were able to make decisions, solve problems, objectively think and talk about the challenge $(p<0.01)$. PBL enhanced their ability to find online and library content, encouraged them to do more work, and improved their SDL capability (Table-1).

Students found that in PBL they were responsible for learning alone, they were able to process information effectively and use their previous understanding to improve their knowledge much more than in CBL. The function of the facilitator was found by the students to be more effective in PBL $(\mathrm{p}<0.001)$, yet they suggested that facilitators be properly trained before implementing it (Table-1). The group will self-evaluate itself in PBL sessions, according to the students, and marks of this assessment should be applied at the end of the semester $(p<0.01)$. In contrast, critical thinking skills were improved in such a way that students attending PBL sessions scored higher marks than 
students attending regular lectures alone [31]. Students were able to identify the purpose of brainstorming the possible choices, taking decisions and evaluating each choice after attending PBL. Students use their decision-making skills to solve problems by choosing one course of action during PBL from several possible alternatives that may be useful in professional life [32].

Throughout supporting research on nursing practitioners, those who graduated with a PBL-based program gained skills and decision to learn. By carrying out PBLs, the decision-making skills of respiration therapy students have also been improved [33]. Developing this skill can help in time management and ultimately help future doctors save lives. By carrying out PBLs, the decision-making skills of respiration therapy students have also been improved.

Educational constructivism believes that students are actively building their information networks, generating context and developing personal world definitions based on individual experiences and interactions [34]. As an academic approach, PBL integrates several elements from the philosophy of adult learning and helps students gain knowledge and develop skills, attitudes and behaviors for successful success in a chosen field [35]. At the same time, PBL stresses individuals ' ability to design and incorporate their own learning methods. Most of the students claimed that the PBL sessions better defined their areas of weakness. The teaching technique inspired the students to realize that it further enabled them to develop future research hypotheses.

\section{Conclusion}

The PBL was effective in terms of idea retention, critical reasoning and problem-solving strategies, but satisfied with the current educational system elucidated CBL's role in the first two years of undergraduate medical training in preparing students through controlled investigation and clinical scenarios presentation. Proper facilitator preparation will be a key point to enhance student learning by PBLs. 
Table 1: Description of Demographic Characteristics

\begin{tabular}{|c|c|c|}
\hline Variables & Number (n) & Percent \\
\hline Gender & & \\
\hline Male & 83 & $60.1 \%$ \\
\hline Female & 48 & $36.1 \%$ \\
\hline Age (years) & & \\
\hline $18 \_22$ & 16 & $12.0 \%$ \\
\hline $22 \_26$ & 110 & $82.7 \%$ \\
\hline above26 & 5 & $3.8 \%$ \\
\hline Background & & \\
\hline rural & 15 & $11.3 \%$ \\
\hline urban & 99 & $74.4 \%$ \\
\hline semi urban & 17 & $12.8 \%$ \\
\hline Study year & & \\
\hline 3rd_year & 46 & $34.6 \%$ \\
\hline 4th_year & 85 & $63.9 \%$ \\
\hline Marital status & \multirow[b]{2}{*}{120} & \multirow{4}{*}{$\begin{array}{r}90.2 \% \\
3.0 \% \\
5.3 \%\end{array}$} \\
\hline Single & & \\
\hline Married & \multirow{2}{*}{$\begin{array}{l}4 \\
7\end{array}$} & \\
\hline engaged & & \\
\hline Seat & \multirow{4}{*}{$\begin{array}{l}5 \\
8\end{array}$} & \multirow{4}{*}{$\begin{array}{l}3.8 \% \\
6.0 \%\end{array}$} \\
\hline Local & & \\
\hline Foreign & & \\
\hline over seas & & \\
\hline
\end{tabular}


Table. 2: perceptions of the students 'about Case base learning and problem base learning.

\begin{tabular}{|c|c|c|c|}
\hline & Statement & $\begin{array}{l}\text { Positive } \\
\text { reflection of } \\
\text { PBL } \\
\text { N }(\%)\end{array}$ & $\begin{array}{l}\text { Negative } \\
\text { reflection } \\
\text { of PBL } \\
\mathrm{N}(\%)\end{array}$ \\
\hline 1. & $\begin{array}{l}\text { The PBL strategy is } \\
\text { interesting as compared } \\
\text { to case based learning } \\
(\mathrm{CBL}) \text {. }\end{array}$ & $95(71.4 \%)$ & $5(3.9 \%)$ \\
\hline 2. & $\begin{array}{l}\text { The knowledge gained } \\
\text { by PBL is more than it } \\
\text { would be by CBL. }\end{array}$ & $85(63.2 \%)$ & $5(3.8 \%)$ \\
\hline 3. & $\begin{array}{l}\text { PBL identifies gaps in } \\
\text { knowledge more than } \\
\text { CBL }\end{array}$ & $84(63.2 \%)$ & $5(3.8 \%)$ \\
\hline 4. & $\begin{array}{l}\text { Real medical problems } \\
\text { are explained better by } \\
\text { PBL as compared to } \\
\text { CBL }\end{array}$ & $25(18.8 \%)$ & $5(3.8 \%)$ \\
\hline 5. & $\begin{array}{l}\text { Objectives of the course } \\
\text { are understood better } \\
\text { by PBL }\end{array}$ & $25(18.8 \%)$ & $5(3.8 \%)$ \\
\hline 6. & $\begin{array}{l}\text { Time taken by PBL is } \\
\text { more than CBL }\end{array}$ & $36(27.1 \%)$ & $5(3.8 \%)$ \\
\hline 7. & $\begin{array}{l}\text { Knowledge is organized } \\
\text { around problem rather } \\
\text { than discipline more by } \\
\text { PBL }\end{array}$ & $54(40.6 \%)$ & $5(3.8 \%)$ \\
\hline 8. & $\begin{array}{l}\text { Learner assumes } \\
\text { responsibility for their } \\
\text { own learning in PBL }\end{array}$ & $54(40.6 \%)$ & $5(3.8 \%)$ \\
\hline 9. & $\begin{array}{l}\text { Learners become } \\
\text { active processors of } \\
\text { information in PBL as } \\
\text { compared to CBL }\end{array}$ & $54(40.6 \%)$ & $5(3.8 \%)$ \\
\hline
\end{tabular}




\begin{tabular}{|c|c|c|c|}
\hline 10. & $\begin{array}{l}\text { Learners activate prior } \\
\text { knowledge and learn to } \\
\text { elaborate } \\
\text { knowledge more by } \\
\text { PBL }\end{array}$ & $33(24.8 \%)$ & $5(3.8 \%)$ \\
\hline 11. & $\begin{array}{l}\text { PBL stimulates } r \text { in } \\
\text { doing research more } \\
\text { than } \mathrm{CBL}\end{array}$ & $67(50.3 \%)$ & $5(3.8 \%)$ \\
\hline 12. & $\begin{array}{l}\text { PBL enhances the } \\
\text { ability to find the } \\
\text { information using the } \\
\text { internet/library more } \\
\text { than CBL }\end{array}$ & $67(50.3 \%)$ & $5(3.8 \%)$ \\
\hline 13. & $\begin{array}{l}\text { PBL helps in identifying } \\
\text { the areas of weakness } \\
\text { for Improvement more } \\
\text { than CBL }\end{array}$ & $56(42.1 \%)$ & $5(3.8 \%)$ \\
\hline 14. & $\begin{array}{l}\text { PBL enables the learner } \\
\text { to establish a concrete } \\
\text { action plan to achieve } \\
\text { their learning goals } \\
\text { more than CBL }\end{array}$ & $55(41.4 \%)$ & $5(3.8 \%)$ \\
\hline 15. & $\begin{array}{l}\text { PBL enhances the } \\
\text { ability to speak in front } \\
\text { of people more than } \\
\text { CBL }\end{array}$ & $55(41.4 \%)$ & $5(3.8 \%)$ \\
\hline 16. & $\begin{array}{l}\text { PBL increases ability to } \\
\text { manage the time } \\
\text { effectively as compared } \\
\text { to CBL }\end{array}$ & $99(74.4 \%)$ & $4(3.1 \%)$ \\
\hline 17. & $\begin{array}{l}\text { PBL helps to convert } \\
\text { from passive to active } \\
\text { life long learner }\end{array}$ & $84(63.2 \%)$ & $5(3.8 \%)$ \\
\hline 18. & $\begin{array}{l}\text { The role of facilitator in } \\
\text { the process is helpful in } \\
\text { PBL more than CBL }\end{array}$ & $104(78.2 \%)$ & $5(3.8 \%)$ \\
\hline
\end{tabular}




\begin{tabular}{|c|c|c|c|}
\hline 19. & $\begin{array}{l}\text { PBL improves the } \\
\text { decision-making skills } \\
\text { more than CBL }\end{array}$ & $104(78.2 \%)$ & $5(3.1 \%)$ \\
\hline 20. & $\begin{array}{l}\text { PBL improves the } \\
\text { problem-solving skills } \\
\text { more than CBL }\end{array}$ & $66(49.6 \%)$ & $5(3.8 \%)$ \\
\hline 21. & $\begin{array}{l}\text { PBL develops the } \\
\text { competence in self- } \\
\text { directed learning more } \\
\text { than CBL }\end{array}$ & $4(3.5 \%)$ & $5(3.8 \%)$ \\
\hline 22. & $\begin{array}{l}\text { PBL improves } \\
\text { communication skills } \\
\text { more than CBL }\end{array}$ & $46(34.6 \%)$ & $5(3.8 \%)$ \\
\hline 23. & $\begin{array}{l}\text { PBL helps in managing } \\
\text { patients more than CBL }\end{array}$ & $46(34.6 \%)$ & $5(3.8 \%)$ \\
\hline 24. & $\begin{array}{l}\text { PBL enables skill of } \\
\text { critical reasoning more } \\
\text { than CBL }\end{array}$ & $46(34.6 \%)$ & $5(3.8 \%)$ \\
\hline 25. & $\begin{array}{l}\text { The proper training of } \\
\text { PBL should be given } \\
\text { before its } \\
\text { implementation }\end{array}$ & $46(34.6 \%)$ & $5(3.8 \%)$ \\
\hline 26. & $\begin{array}{l}\text { The group assessment } \\
\text { mark should be used } \\
\text { towards the semester } \\
\text { examination marks } \\
\text { (semester use) }\end{array}$ & $46(34.6 \%)$ & $5(3.8 \%)$ \\
\hline 27. & $\begin{array}{l}\text { Awarding an individual } \\
\text { mark to each student } \\
\text { would be a fairer } \\
\text { reflection of an } \\
\text { individual's } \\
\text { performance in the } \\
\text { group. }\end{array}$ & $86(64.7 \%)$ & $5(3.8 \%)$ \\
\hline 28. & $\begin{array}{l}\text { The group should } \\
\text { evaluate themselves } \\
\text { against the objectives } \\
\text { they set early rather }\end{array}$ & $51(38.3 \%)$ & $5(3.8 \%)$ \\
\hline
\end{tabular}




\begin{tabular}{|l|l|l|l|}
\hline & than by the tutor & & \\
\hline 29. & $\begin{array}{l}\text { The assessment marks } \\
\text { should be used for } \\
\text { guiding the group and } \\
\text { not towards the } \\
\text { summative semester } \\
\text { examination marks }\end{array}$ & $\mathbf{5 1 ( 3 8 . 3 \% )}$ & $\mathbf{5 ( 3 . 8 \% )}$ \\
\hline 30. & $\begin{array}{l}\text { The teaching tool will } \\
\text { help you to perform } \\
\text { better in University } \\
\text { exams statement }\end{array}$ & $\mathbf{5 1 ( 3 8 . 3 \% )}$ & $\mathbf{5 ( 3 . 8 \% )}$ \\
\hline 31. & $\begin{array}{l}\text { Are you satisfied with } \\
\text { the current system of } \\
\text { education }\end{array}$ & $\mathbf{5 1 ( 3 8 . 3 \% )}$ & $\mathbf{5 ( 3 . 8 \% )}$ \\
\hline
\end{tabular}

\section{Acknowledgment}

I would like to thank the following people who in many ways contributed to this piece of work. First and foremost, I would like to thank Mr. Muhammad Afzal (The Principal of Lahore School of Nursing) who allowed me to do this study and guided me. I would thank to Mr. Hussain and Allah wasayababar for being my supervisor and for being the greatest inspiration for my work. It is a great pleasure to have all of these wonderful people in my life. I thank the management of University of Lahore.

\section{References}

1. Asad M, Iqbal K, Sabir M. Effectiveness of problem based learning as a strategy to foster problem solving and critical reasoning skills among medical students. Journal of Ayub Medical College Abbottabad. 2015;27(3):604-7.

2. Asad M, Mahfod J. Training and development and its impact on the employee's performance: A study of agility companyKingdom of Bahrain. International Review of Management and Business Research. 2015;4(3):700.

3. Vogt K, Pelz J, Stroux A. Refinement of a training concept for tutors in problem-based learning. GMS journal for medical education. 2017;34(4). 
4. Ricci G, Cipriani F, Cuello-Garcia CA, Brożek JL, Fiocchi A, Pawankar R, et al. A c linical reading on "world allergy organization-mcmaster university guidelines for allergic disease prevention (glad-p): probiotics". World Allergy Organization Journal. 2016;9(1):9.

5. Georgiou A, Grain H, Schaper LK. Driving reform: digital health is everyone's business: selected papers from the 23rd Australian National Health Informatics Conference (HIC 2015): IOS Press; 2015.

6. Lamer A, De Jonckheere J, Marcilly R, Tavernier B, Vallet B, Jeanne $\mathrm{M}$, et al. A substitution method to improve completeness of events documentation in anesthesia records. Journal of clinical monitoring and computing. 2015;29(6):741-7.

7. Avelino J, Cristancho $\mathrm{M}$, Georgiou S, Imbach $\mathrm{P}$, Aguilar L, Bornemann $\mathrm{G}$, et al. The coffee rust crises in Colombia and Central America (2008-2013): impacts, plausible causes and proposed solutions. Food Security. 2015;7(2):303-21.

8. Demirören M, Turan S, Öztuna D. Medical students' self-efficacy in problem-based learning and its relationship with self-regulated learning. Medical education online. 2016;21(1):30049.

9. McLean RD, Pontiff J. Does academic research destroy stock return predictability? The Journal of Finance. 2016;71(1):5-32.

10. Kumar N, Kanchan T, Unnikrishnan B, Thapar R, Mithra P, Kulkarni $\mathrm{V}$, et al. Incorporating problem based learning into medical curriculum: An experience from a medical college in Mangalore. Indian journal of pharmacology. 2017;49(5):344.

11. Constantinou CS, Nicolaou SA. Motivation, Challenges, Support (MCS) Cycle Model for the Development of PBL Tutors. Qualitative Research in Education. 2018;7(1):1-35.

12. HangFu L, Nauhria S. Principles for designing accountability and responsibility plan in medical education that spreads across multiple sites. MedEdPublish. 2019;8.

13. Prihatiningsih TS, Qomariyah N. Evaluation of a Problem Based Learning Curriculum Using Content Analysis. International Journal of Evaluation and Research in Education. 2016;5(3):20510 .

14. Karunathilake H, Hewage K, Mérida W, Sadiq R. Renewable energy selection for net-zero energy communities: Life cycle 
based decision making under uncertainty. Renewable energy. 2019;130:558-73.

15. Liu J, Yang Q, Wang D, Li X, Zhong Y, Li X, et al. Enhanced dewaterability of waste activated sludge by $\mathrm{Fe}$ (II)-activated peroxymonosulfate oxidation. Bioresource technology. 2016;206:134-40.

16. Huang $\mathrm{C}$, Wang $\mathrm{Y}$, Li X, Ren $\mathrm{L}$, Zhao J, Hu Y, et al. Clinical features of patients infected with 2019 novel coronavirus in Wuhan, China. The Lancet. 2020;395(10223):497-506.

17. Singh P. CBL in Medical Education Effective Learning Methodology than PBL [J]. Int J Intg Med Sci. 2015;2(8):145-50.

18. Ali HS, Suliman RS, Khan SA, Elhaj B, Asmani F, Khan J, et al. Experience of Dubai Pharmacy College with PBL through Students' Perception. learning. 2017;13:14.

19. Karunathilake I. Role of Problem-Based Learning (PBL) in Postgraduate Medical Education. Journal of the Postgraduate Institute of Medicine. 2019;6(1).

20. Nguyen TAP, Kang S, Ho TTT, Mai BH, Vo TDB, Nguyen VQH. Problem-based learning in nursing education at Hue university of medicine and pharmacy, Vietnam: Perspective and needs assessment. Journal of Problem-Based Learning. 2016;3(1):9-14.

21. Sule R. Medical Students and Faculty Perceptions Towards a Case Based Learning Intervention at an Indian Medical College 2016.

22. Jeong M-E, Park H-S. Effects of case-based learning on clinical decision making and nursing performance in undergraduate nursing students. Journal of Korean Academy of Fundamentals of Nursing. 2015;22(3):308-17.

23. Mahmood SU, Syed F, Khan NR, Batool Z, Rehman R. COMPARISON OF PROBLEM BASED WITH CASE BASED LEARNING: A CROSS-SECTIONAL STUDY. Pak J Physiol. 2017;13(4):52-6.

24. Azzeh M, Nassif AB. A hybrid model for estimating software project effort from Use Case Points. Applied Soft Computing. 2016;49:981-9.

25. Balakrishnan V, Gan CL. Students' learning styles and their effects on the use of social media technology for learning. Telematics and Informatics. 2016;33(3):808-21. 
26. Weintrop D, Wilensky U, editors. To block or not to block, that is the question: students' perceptions of blocks-based programming. Proceedings of the 14th international conference on interaction design and children; 2015.

27. Pathak A, Intratat C. Use of semi-structured interviews to investigate teacher perceptions of student collaboration. Malaysian Journal of ELT Research. 2016;8(1):10.

28. Zheng S, Rosson MB, Shih PC, Carroll JM, editors. Understanding student motivation, behaviors and perceptions in MOOCs. Proceedings of the 18th ACM conference on computer supported cooperative work \& social computing; 2015.

29. Selwyn N, Gorard S. Students' use of Wikipedia as an academic resource-Patterns of use and perceptions of usefulness. The Internet and Higher Education. 2016;28:28-34.

30. Hung C-Y, Sun JC-Y, Yu P-T. The benefits of a challenge: student motivation and flow experience in tablet-PC-game-based learning. Interactive Learning Environments. 2015;23(2):172-90.

31. Tomlinson, M. (2017). Student perceptions of themselves as 'consumers' of higher education. British Journal of Sociology of Education, 38(4), 450-467.

32. Hainey T, Connolly TM, Boyle EA, Wilson A, Razak A. A systematic literature review of games-based learning empirical evidence in primary education. Computers \& Education. 2016;102:202-23.

33. Paolini A. Enhancing Teaching Effectiveness and Student Learning Outcomes. Journal of Effective Teaching. 2015;15(1):20-33.

34. Flores MA, Veiga Simão AM, Barros A, Pereira D. Perceptions of effectiveness, fairness and feedback of assessment methods: a study in higher education. Studies in Higher Education. 2015;40(9):1523-34.

35. Freeze RD, Alshare KA, Lane PL, Wen HJ. IS success model in e-learning context based on students' perceptions. Journal of Information systems education. 2019;21(2):4. 